doi: 10.2306/scienceasia1513-1874.2010.36.161

\title{
In vitro flowering of shoots regenerated from cultured nodal explants of Rosa hybrida cv. 'Heirloom'
}

\author{
Kantamaht Kanchanapoom ${ }^{\mathrm{a}}$, Patthara Sakpeth ${ }^{\mathrm{a}}$, Kamnoon Kanchanapoom ${ }^{\mathrm{b}, *}$ \\ a Centre for Genomics and Bioinformatics Research, Faculty of Science, Prince of Songkla University, \\ Hat Yai, Songkhla, 90112 Thailand \\ b Department of Biology, Faculty of Science, Prince of Songkla University, Hat Yai, Songkhla, 90112 Thailand \\ ${ }^{*}$ Corresponding author, e-mail: kamnoon_k@yahoo.co.th
}

Received 22 Dec 2009

Accepted 20 May 2010

\begin{abstract}
A protocol to culture nodal explants of Rosa hybrida cv. 'Heirloom' in vitro was developed. Multiple shoot formation of up to 3 shoots were obtained on Murashige and Skoog (MS) medium supplemented with $13.3 \mathrm{mM}$ BA and 9.3 mM kinetin. Regenerated shoots cultured on MS medium containing various concentrations of BA, kinetin, and sucrose did not flower. Flower induction occurred when regenerated shoots were cultured on MS medium supplemented with 13.3 mM BA and 9.3 mM kinetin under photoperiod of 12/12 (light/dark cycle). The 3-week intervals for two consecutive subcultures on this medium were efficient for flower induction. Shoots readily rooted on 1/4 MS medium were found to be devoid of growth regulators. Rooted plantlets were hardened and established in pots at $100 \%$ survival.
\end{abstract}

KEYWORDS: micropropagation, nodal culture, photoperiod, rose, subculture time

\section{INTRODUCTION}

The flowering process is one of the critical events in the life of a plant. This process involves the switch from vegetative stage to reproductive stage of growth and is believed to be regulated by both internal and external factors. A flowering system in vitro is considered to be a convenient tool to study specific aspects of flowering, floral initiation, floral organ development, and floral senescence ${ }^{1}$. The application of cytokinins, sucrose concentrations, photoperiod, and subculture time to promote flowering in vitro is well documented in many plant species including roses ${ }^{2,3}$. Rose is an important perennial flower shrub or vine of the genus Rosa, within the family Rosaceae that contains over 100 species and comes in a variety of colours, shapes, and sizes. Roses are one of the most important ornamentals and are most often used for ornamental, medicinal, and aromatic purposes.

Tissue culture systems in roses have already been established $^{4-12}$. To establish a flowering research system in vitro, it is necessary to develop a reliable and rapid shoot organogenesis protocol. In this context we describe an efficient protocol for the culturing and flowering of Rosa hybrida L. cv. 'Heirloom' in vitro. This study is part of a larger programme designed to investigate the flowering of Rosa species in vitro.

\section{MATERIALS AND METHODS}

\section{Plant materials}

The Heirloom rose, a beautiful and intensely fragrant rose with a wide range of colours, was used throughout the experiment. Nodal explants containing lateral buds of actively field-grown 'Heirloom' roses were cut into $3 \mathrm{~cm}$ length segments, washed in running water to remove the dirt, and used for multiplication experiments. To sterilize the surface, these segments were treated with $70 \%$ ethanol for $15 \mathrm{~s}$ and then immersed in $20 \%$ (v/v) Clorox solution of commercial laundry bleach $(5.25 \% \mathrm{NaOCl})$ containing 2 drops of Tween-20 emulsifier to aid wetting for $20 \mathrm{~min}$. After the surface decontamination was done, the sterilized explants were rinsed 2-3 times with sterile distilled water to remove the disinfecting solution. They were trimmed to $1 \mathrm{~cm}$ lengths prior to transfer to the culture medium.

\section{Medium preparation}

Murashige and Skoog ${ }^{13}$ (MS) salts and vitamins supplemented with $30 \mathrm{~g} / \mathrm{l}$ sucrose were used as the basal medium. Mermaid agar $(8.2 \mathrm{~g} / \mathrm{l})$ was used as a gelling agent. The $\mathrm{pH}$ of all media was adjusted to 5.8 with $1 \mathrm{~N} \mathrm{NaOH}$ or $1 \mathrm{~N} \mathrm{HCl}$ prior to autoclaving at $1.05 \mathrm{~kg} / \mathrm{cm}^{2}, 121^{\circ} \mathrm{C}$ for $20 \mathrm{~min}$. 


\section{Culture conditions}

Cultures were maintained at $25 \pm 1{ }^{\circ} \mathrm{C}$ air temperatures in a culture room with a $16 / 8 \mathrm{~h} \mathrm{light/dark} \mathrm{pho-}$ toperiod under an illumination of $20 \mathrm{mmol} \mathrm{m}^{-2} \mathrm{~s}^{-1}$ photosynthetic photon flux intensity provided by coolwhite fluorescent light unless otherwise stated. Plant materials were stored in glass-capped culture jars (115 ml capacity) each containing $20 \mathrm{ml}$ of medium. A culture cycle was 3 weeks. After this period the plants were transferred to fresh medium or used for root induction. To establish root proliferation, green and normal adventitious shoots from shoot multiplication cultures were excised and placed on 1/4 MS devoid of growth regulator. When adequate rooted shoots were obtained, the plantlets were transferred to $330 \mathrm{ml}$ screw-topped jars containing sterile vermiculite for 2 weeks for hardening.

To test the effect of cytokinins on multiple shoot formation, BA and kinetin were employed. The nodal explants were aseptically cultured on MS medium supplemented with $0,4.4,8.8,13.3 \mathrm{mM} \mathrm{BA}$ or $0,4.6$, 9.3, $13.9 \mathrm{mM}$ kinetin either singly or in combination. To examine the effect of sucrose, 5 concentrations of sucrose $(0,10,30,50$, or $70 \mathrm{~g} / \mathrm{l})$ were added to MS medium supplemented with $13.3 \mathrm{mM}$ BA and $9.3 \mathrm{mM}$ kinetin. Explants were incubated as previously described for 9 weeks. To examine the effect of photoperiod, 3 light/dark cycles i.e., 12/12, $16 / 8$, and $8 / 16$ were used in monitoring flowering in vitro. To examine the subculture time, explants were subcultured to fresh MS medium supplemented with $13.3 \mathrm{mM}$ BA and $9.3 \mathrm{mM}$ kinetin every 3 weeks.

\section{Statistical analysis}

One explant $(1 \mathrm{~cm}$ long $)$ was planted per culture and 20 cultures were raised for each treatment. All experiments were conducted on 3 different days. Data were analysed by ANOVA and the difference between the means was compared using Tukey's test at $p \leqslant$ 0.05 .

\section{RESULTS AND DISCUSSION}

After 3 weeks of initial culture, nodal explants cultured on MS medium with several concentrations of BA and kinetin developed multiple shoots. Results obtained revealed that $13.3 \mathrm{mM}$ BA in combination with $9.3 \mathrm{mM}$ kinetin gave the highest number of shoots $(3.6 \pm 0.5, p \leqslant 0.05)$. There was a significant difference in shoot number per explant (Table 1). This may suggest that bud formation in this cultivar required cytokinins. No callus formation was observed at all tested concentrations. Other researchers have
Table 1 Effect of different combinations of BA and kinetin on multiple shoot formation of Rosa hybrida cv. 'Heirloom' cultured on MS medium.

\begin{tabular}{lcc}
\hline BA $(\mathrm{mM})$ & Kinetin $(\mathrm{mM})$ & $\begin{array}{c}\text { Number of shoots per explant } \\
(\text { Mean } \pm \mathrm{SE})\end{array}$ \\
\hline 0 & 0 & $1.0 \pm 0.0^{\mathrm{ef}}$ \\
4.4 & 0 & $1.0 \pm 0.0^{\mathrm{ef}}$ \\
8.8 & 0 & $2.0 \pm 0.0^{\mathrm{bcde}}$ \\
13.3 & 0 & $2.0 \pm 0.0^{\mathrm{bcde}}$ \\
0 & 4.6 & $1.0 \pm 0.0^{\mathrm{ef}}$ \\
0 & 9.3 & $1.3 \pm 0.1^{\mathrm{def}}$ \\
0 & 13.9 & $1.4 \pm 0.1^{\mathrm{de}}$ \\
4.4 & 4.6 & $1.4 \pm 0.1^{\mathrm{de}}$ \\
4.4 & 9.3 & $1.6 \pm 0.1^{\mathrm{de}}$ \\
4.4 & 13.9 & $1.8 \pm 0.3^{\mathrm{cde}}$ \\
8.8 & 4.6 & $2.0 \pm 0.4^{\mathrm{bcde}}$ \\
8.8 & 9.3 & $2.2 \pm 0.4^{\mathrm{bcde}}$ \\
8.8 & 13.9 & $3.1 \pm 0.4^{\mathrm{abc}}$ \\
13.3 & 4.6 & $3.2 \pm 0.5^{\mathrm{ab}}$ \\
13.3 & 9.3 & $3.6 \pm 0.5^{\mathrm{a}}$ \\
13.3 & 13.9 & $2.7 \pm 0.3^{\mathrm{abcd}}$ \\
\hline
\end{tabular}

Differing superscripts within a column show significant differences by ANOVA and Tukey's test at $p \leqslant 0.05$.

obtained different results for other roses with the combination of BA and $\mathrm{NAA}^{2,3,11}$, or BA and IBA ${ }^{14,15}$. Therefore MS medium containing $13.3 \mathrm{mM}$ BA and $9.3 \mathrm{mM}$ kinetin was considered as optimal for shoot proliferation and the shoots with green expanded leaves and single main stem regenerated in vitro were further multiplied on this medium. Clonal propagation of Heirloom rose was achieved by subculture at 3 week intervals. We routinely used this protocol for multiplication of shoots used in the subsequent experiments.

In vitro flowering was not observed on MS medium containing BA and kinetin after 9 weeks of culture (Table 1). Cytokinins are believed to induce molecular changes associated with the floral transition ${ }^{16}$. BA has been used for most experiments on flowering in vitro of roses ${ }^{2,3,17}$ and several other plant species $^{18-20}$.

The effect of sucrose on individual shoot formation was recorded after 9 weeks of culture. Table 2 indicates that the sucrose concentrations did not influence flowering in vitro. Sucrose is generally known as the carbon source for the vegetative growth and development of flowers. The effects of sucrose on shoots bearing floral buds were reported in a number of species such as Fortunella hindsii ${ }^{21}$, Fagopyrum esculentum $^{22}$, rose (hybrid tea) cv. 'First Prize' ${ }^{3}$. 
Table 2 Effect of sucrose on multiple shoot formation in Rosa hybrida cv. 'Heirloom' cultured on MS medium supplemented with $13.3 \mathrm{mM}$ BA and $9.3 \mathrm{mM}$ kinetin.

\begin{tabular}{lc}
\hline Sucrose concentration (g/l) & $\begin{array}{c}\text { Number of shoots per explant } \\
\text { (Mean } \pm \text { SE) }\end{array}$ \\
\hline 0 & $1.0 \pm 0.0$ \\
10 & $2.9 \pm 0.3$ \\
30 & $2.7 \pm 0.3$ \\
50 & $3.7 \pm 0.5$ \\
70 & $3.2 \pm 0.5$ \\
\hline
\end{tabular}

However, BA, kinetin and sucrose were unable to induce flowering in our system, perhaps due to cultivardependent differences.

Length of photoperiod, recorded after 9 weeks of culture, showed no significant effect on shoot multiplication but did influence flowering in vitro. The percentage of flowering was $60 \%$ indicating that the flowering stimulus did occur. Demeulemeester and DeProft ${ }^{23}$ proposed that the age of mother plants influences flower induction of chicory. Hence, it is possible that the explants used in this study were at the transition phase.

The effect of subculture time on flower induction in vitro was examined. After two consecutive subcultures, the $80 \%$ of the plants were flowering. The flowers were small, had normal petals and sepals, and proceeded to open (Fig. 1). It seems that a period of 6 weeks in culture was appropriate for flowering in the present study. This is probably because differentiation to floral phase reached a peak after two consecutive subcultures. Wang et $\mathrm{al}^{2}$ stated that subculture time before flower induction could substantially affect in vitro flowering.

Regenerated shoots were excised and transferred to $1 / 4 \mathrm{MS}$ medium without growth regulators to induce roots. Rooted shoots were incubated for two weeks prior to transplanting to polystyrene pots containing soil mixture (1 sand: 1 manure: 1 decayed leaves). In vitro-derived plants did not display any phenotypic variation during subsequent vegetative development.

\section{CONCLUSIONS}

A micropropagation system for Rosa hybrida cultivar 'Heirloom' has been developed using nodal explants. Regenerated shoots could flower under certain photoperiod and subculture times. Although in vitro flowering was observed, more reliable culture regimes need to be elucidated.

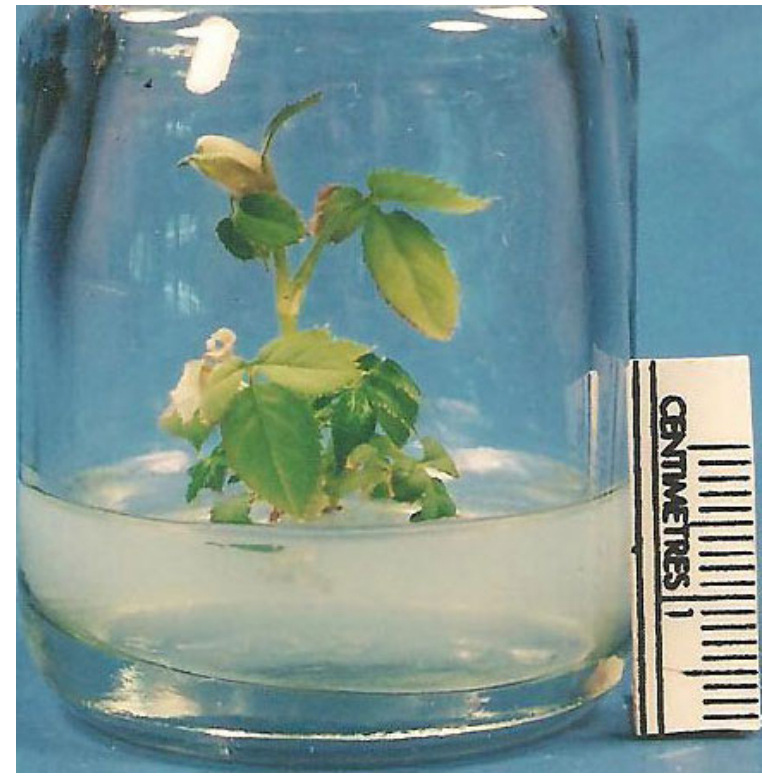

Fig. 1 The rose shoot cultured on MS medium cultured on MS medium supplemented with $13.3 \mathrm{mM} \mathrm{BA}$ and $9.3 \mathrm{mM}$ kinetin flowered in vitro after two subcultures.

Acknowledgements: This research was financially supported by the Faculty of Science, Prince of Songkla University.

\section{REFERENCES}

1. Goh CJ (1992) Studies on flowering in orchids - A review and future directions. In: Proceedings of Nagoya International Orchid Show '92, pp 44-9.

2. Wang GY, Yuan MF, Hong Y (2002) In vitro flower induction in roses. Vitro Cell Dev Biol Plant 38, 513-8.

3. Vu NH, Anh PH, Nhut DT (2006) The role of sucrose and different cytokinins in the in vitro floral morphogenesis of rose (hybrid tea) cv. 'First Prize'. Plant Cell Tissue Organ Cult 87, 315-20.

4. Hsia CN, Korban SS (1996) Organogenesis and somatic embryogenesis in callus cultures of Rosa hybrida and Rosa chinensis minima. Plant Cell Tissue Organ Cult 44, 1-6.

5. Douglas GC, Rutledge CB, Casey AD, Richardson DHS (1998) Micropropagation of floribunda ground cover and miniature roses. Plant Tissue Culture 19, $55-64$.

6. Kintzios S, Manos C, Makri O (1999) Somatic embryogenesis from mature leaves of rose (Rosa sp.). Plant Cell Rep 18, 467-72.

7. Ibrahim R, Debergh PC (2001) Factors controlling high efficiency of adventitious bud formation and plant regeneration from in vitro leaf explants of roses (Rosa hybrida). Sci Hort 88, 41-57.

8. Kim SW, Oh SC, In DS, Liu JR (2003) Plant regeneration of rose (Rosa hybrida) from embryogenic cell- 
derived protoplasts. Plant Cell Tissue Organ Cult 73, $15-9$.

9. Rout GR, Mohapatra A, Mohan Jain S (2006) Tissue culture of ornamental pot plant: A critical review on present scenario and future prospect. Biotechnol Adv 24, 531-60.

10. Hameed N, Shabbir A, Ali A, Bajwa R (2006) In vitro micropropagation of disease free rose (Rosa indica $\mathrm{L}$.). Mycopathologia 4, 35-8.

11. Drefahl A, Quoirin MG, Cuquel FL (2007) Micropropagation of Rosa $\times$ hybrida cv. Vegas via axillary buds. Acta Hort 751, 407-11.

12. Previati A, Benelli C, Da Re F, Ozudogru A, Lambardi M (2008) Micropropagation and in vitro conservation of virus-free rose germplasm. Propag Ornam Plant 8 , 93-8.

13. Murashige T, Skoog F (1962) A revised medium for rapid growth and bioassays with tobacco tissue cultures. Physiol Plantarum 15, 473-97.

14. Kumar A, Sood A, Plani UT, Gupta AK, Plani LMS (2001) Micropropagation of Rosa damascena Mill. from mature bushes using thidiazuron. J Hort Sci Biotechnol 76, 30-4.

15. Khosh-Khui M, Jabbarzadeh Z (2007) Effects of several variables on in vitro culture of Damask Rose (Rosa damascena Mill.). Acta Hort 751, 389-93.

16. Bernier G, Corbesier L, Perilleux C (2002) The flowering process: on the track of controlling factors in Sinapsis alba. Russ J Plant Physiol 49, 445-50.

17. Dobres M, Williams L, Gail R (1998) Micropropagation of rose plants. US patent 5,843,782.

18. Kostenyuk I, Oh BJ, So IS (1999) Induction of early flowering in Cymbidium niveomarginatum Mak in vitro. Plant Cell Rep 19, 1-5.

19. Lin CC, Lin CS, Chang WC (2003) In vitro flowering of Bambusa edulis and subsequent plantlet survival. Plant Cell Tissue Organ Cult 72, 71-8.

20. Taylor NJ, Light ME, Van Staden J (2005) In vitro flowering of Kniphofia leucocephala: influences of cytokinins. Plant Cell Tissue Organ Cult 83, 327-33.

21. Jumin HB, Nito N (1996) In vitro flowering of Fortunella hindsii (Champ.). Plant Cell Rep 15, 484-8.

22. Kachonpadungkitti Y, Romchatngoen S, Hasegawa K, Hisajima S (2001) Efficient flower induction from cultured buckwheat (Fagopyrum esculentum L.) node segments in vitro. Plant Growth Regul 35, 37-45.

23. Demeulemeester MAC, DeProft MP (1999) In vivo and in vitro flowering response of chicory (Cichorium intybus L.): influence of plant age and vernalization. Plant Cell Rep 18, 781-5. 